\title{
A SHORT HISTORY OF THE DEVELOPMENT OF SOUTH AFRICA'S NAVAL UNIFORM
}

LT CDR W. M. BISSET*

In 1975 Mr Andrew Mollo's Naval, Marine and Air Force Uniforms of World War 2 was published.' This fascinating book contains very little information about our naval uniforms during World War II and since so little has been written about this subject and the uniforms worn by the SA Navy and its predecessors the following article has been compiled. This is a topic on which one could easily write a book and South African Naval Regulations and Instructions Chapter 15 Uniform and Dress Regulations, with amendments to February 1974 is 44 pages long. In December 1968 there were 732 naval uniform badges. ${ }^{2}$ Recently further uniform changes were promulgated and it is understood that SAN Uniform and Dress Regulations are soon to be revised.

However the Royal Naval uniform which our sailors wore until relatively recently has been described elsewhere, so a brief outline of the most significant changes which led to the development of our own naval uniform is a less daunting topic. Our naval buttons have been described in some detail in another article and it is clear that naval badges merit similar treatment.

Although I have not had access to official records, the photograph collection assembled by the SA Naval Museums Branch, photographs published in Commando, Paratus, The Sailor and SA Navy News and information kindly supplied by Naval personnel past and present have made it possible to compile what it is hoped will prove a useful interim report. The writer is particularly grateful to Cdre J. C. Goosen, SM for kindly reading the article and making a number of most helpful suggestions.

Herbert Knötel, Jnr in his Handbuch der Uniformkunde has argued that 'Great Britain has been the decisive factor in the development of Naval uniform.' ${ }^{3}$ A study of Paymaster Lt Cdr Talbot-Booth's All the World's Fighting Fleets published circa 1938 quickly confirms the unbelievable similarity of almost all naval uniforms. For instance the lace curl worn by our naval officers was also worn by naval officers of the following countries in 1938: Brazil, China,
Denmark, Estonia, Great Britain, Hungary, Italy, Japan, Latvia, The Netherlands, Norway, Poland, Portugal, Rumania, Sweden, Turkey and Yugoslavia. $^{4}$

Mr Andrew Mollo has argued that wartime necessity forced the many exiled navies fighting on from England to wear the only available naval uniforms - those of their host country and points out that many of the wartime changes were later retained. ${ }^{5}$

Some excellent photographs of the Natal Naval Volunteers are to be seen in Cdr Hay's History of the RNVR South African Division. Cdr Hay records that the only difference between the lace worn by the officers of the RNR and that first worn by their NNV counterparts was that the latter wore silver lace. However, this was not a South African innovation, merely the continuation of the practice followed by other Royal Naval Artillery Volunteers. ${ }^{6}$

An excellent photograph of AB R.M. McCarthy, reveals that the 'RNVR crown and fouled anchor SOUTH AFRICA' cap tally was worn during or shortly after World War I. RNVR(SA) ratings serving in RN ships replaced their RNVR cap tallies with 'HMS' or RN ship name cap tallies. ${ }^{7}$

Although RN type 'RNVR-SA/KMVR SA' (Koninklike Mariene Vrywilliger Reserwe) buttons exist the fact that the buttons on RNVR officers uniforms in the Naval Museums collection are the usual $\mathrm{RN}$ officers pattern suggests that only a limited number of the RNVR(SA) pattern may have been manufactured although it is also possible that naval tailors used the wrong buttons.

The South African Naval Service (1922-1939) also wore RN uniform with minor modifications. Officers and ratings wore RN type SANS/SASD (SA Seediens) buttons. South African officers wore SANS over SASD badges above the curl in their rank lace. Ratings wore the same letters within an oval ring above the cuff on each sleeve. Although these letters may be seen clearly in old photographs it is not known whether they were 
metal or gold wire badges. Cap tallies bearing the names of our ships HMSAS PROTEA, HMSAS IMMORTELLE, and HMSAS SONNEBLOM and our shore establishment HMSAS AFRIKANDER were worn. Photographs indicate that RN officers seconded to the SANS did not wear the SANS/SASD sleeve badges.

On 15 January 1940, the Seaward Defence Force, a Union Defence Forces unit was formally constituted. Its personnel included the remaining handful of SANS officers and ratings, RNVR(SA) volunteers, RNVR personnel on Ioan, SANS War Reserve, a few retired $\mathrm{RN}$ officers on loan and volunteers. $^{8}$ On 1 August 1942 the RNVR(SA) and Seaward Defence Force were amalgamated to form the SA Naval Forces. Scarcely any changes were made to the typical RN and RNVR uniforms worn by our sailors during World War II. Officers of the RNVR(SA), SDF and SANF wore the orange diamond above the curl in their rank lace in winter uniform and a triangular piece of orange material near the point of their shoulder straps. $R N V R(S A)$ ratings serving in $R N$ ships wore unilingual SOUTH AFRICA shoulder titles but did not wear the orange diamond. The 'RNVR

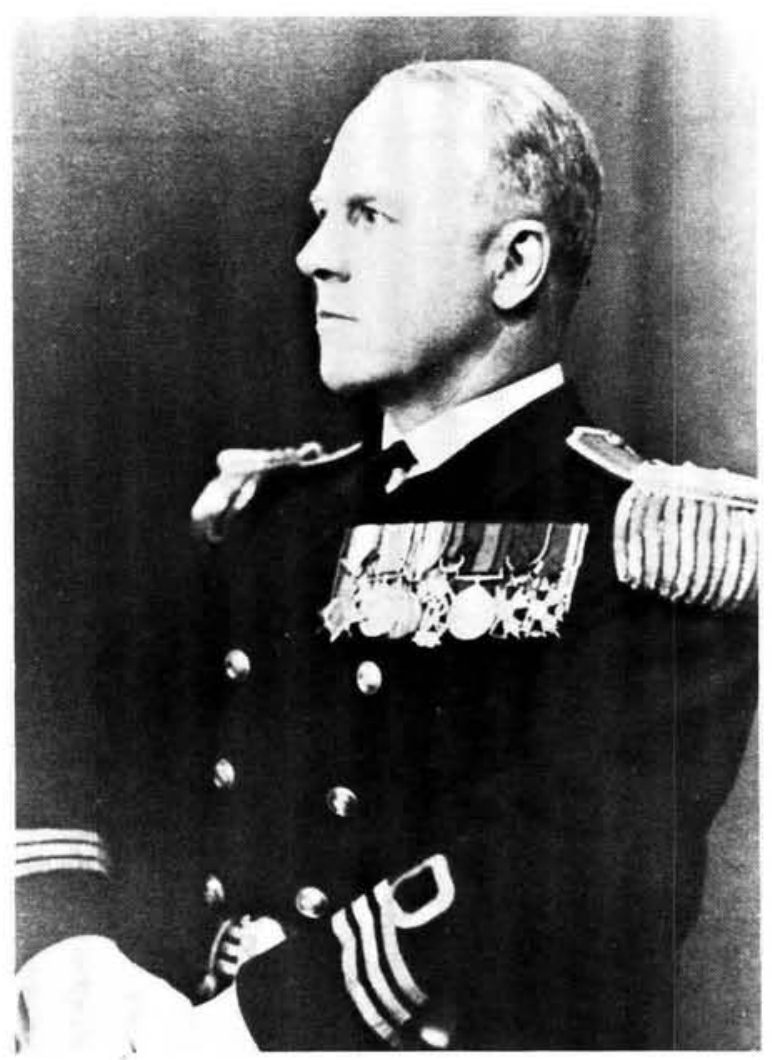

Cdr L. R. Heydenrych, VRD, wearing the full dress uniform which was not worn here after the amalgamation of the RNVR(SA) and SDF in 1942. Notice the fulldress sword belt which has been replaced by the black undress sword belt. crown and fouled anchor SOUTH AFRICA' cap tally was still in use when war was declared.

Seaward Defence Force ratings wore the orange diamond on their sleeves but did not wear shoulder titles. Male SDF ratings wore 'SA Crown and fouled anchor SA' cap tallies. 'S crown and fouled anchor $A^{\prime}$ cap tallies were worn by $S A$ Womens' Auxiliary Naval Service ratings. Some of these cap tallies are the usual gold wire type whilst wartime shortages resulted in others made of gold coloured cotton being manufactured. ${ }^{9}$ Wartime security led to the replacement of RN cap tallies bearing ship names by 'HMS' cap tallies and a South African sailor who served in a British warship has said that these were preferred by his South African shipmates because they were better made than our own. ${ }^{10}$

RNVR(SA) officers wore RNVR rank lace and SDF officers wore $\mathrm{RN}$ rank lace. When the two were amalgamated the $\mathrm{RN}$ lace and orange diamond or orange shoulder strap cloth were worn by the SA Naval Forces officers. The SOUTH AFRICA shoulder titles, orange diamond and ' $S$ crown and fouled anchor A' cap tallies were worn by all SA Naval Forces ratings.

The orange diamonds or shoulder strap cloth indicated that the wearer was a volunteer member of the Union Defence Forces who had undertaken 'to serve anywhere for the duration of the war.' The orange diamonds were disliked by some ratings because those who failed to remove them on washing day risked ruining the white uniform on which they were worn. Our sailors who visited India and Ceylon chose not to wear the orange diamond in those countries in order to avoid an unfriendly reception. Whilst photographs of SDF officers reveal that some wore the wartime austerity half lace on their blue uniform (reefer) jackets, this does not seem to have been the general rule as was the case in England. The half lace was preferred by administrative officers some of whom even wore white sleeves to protect their lace and distinguishing cloth until they were ordered to remove them by Cdre Dalgleish who saw no reason why they should not get their uniforms dirty like other naval officers. ${ }^{11}$

Khaki shorts, shirts, stockings, etc were worn at Saldanha Bay and elsewhere. One photograph shows SANF officers at Saldanha Bay all wearing blue jackets, cap, white shirt, navy blue tie, khaki shorts and stockings and brown or black shoes. A photograph taken in HMSAS TRANSVAAL re- 
veals that a SANF officer was wearing blue battle dress now known as working dress in 1945.

Some SA Womens' Auxiliary Naval Service uniforms are shown in the photograph donated by Mrs G. Hutchinson which illustrates this article. Not shown in the photograph is the SWANS winter watchkeeper's uniform designed by $\mathrm{Cdr} \mathrm{J}$. W. B. Holmes, RNR at Saldanha Bay because SWANS complained that their existing uniforms provided inadequate protection against the cold. This consisted of a six buttoned blue reefer jacket, seaman's jersey, bell bottomed trousers and the usual SWANS navy blue Melton cloth cap. A navy blue drill dress on which blue SOUTH AFRICA shoulder titles and badges were worn was issued as working dress.

The RN Frock Coat and full dress sword belt worn by our SANS and RNVR officers before 1939 were never worn again here after the Second World War. RN type buttons with the letters S and $A$ on either side of the crown and fouled anchor were issued and probably date from the period when the SANF became part of the Permanent Force on 1 May 1946.
On 21 December 1947 HMSAS TRANSVAAL sailed south on a top secret mission (Operation Snoektown) to annexe Marion and Prince Edward Islands. Photographs of those who took part in this expedition show that they wore naval uniform for the annexation ceremonies and the warm woolly khaki army battledress as working dress. Whilst some officers wore shoulder straps others did not. Ribbons were not worn with army battledress and ratings wore no rank or branch badges. The seaman's jersey, web belt, boots, anklets, white scarves and caps without white cap covers were worn with army battledress. The latter RN custom indicated service in a cold climate. Army battledress had been worn by certain RN personnel during World War II.

Although some attempts had been made to create a naval uniform with a uniquely South African identity, it was the Hon F. C. Erasmus, Minister of Defence 1948-1959 who made the greatest single contribution to the achievement of this goal. The wartime orange diamond mentioned above was retained after World War II. In the Army and SA Air Force it had sometimes been the cause of discord so it was understandable that it

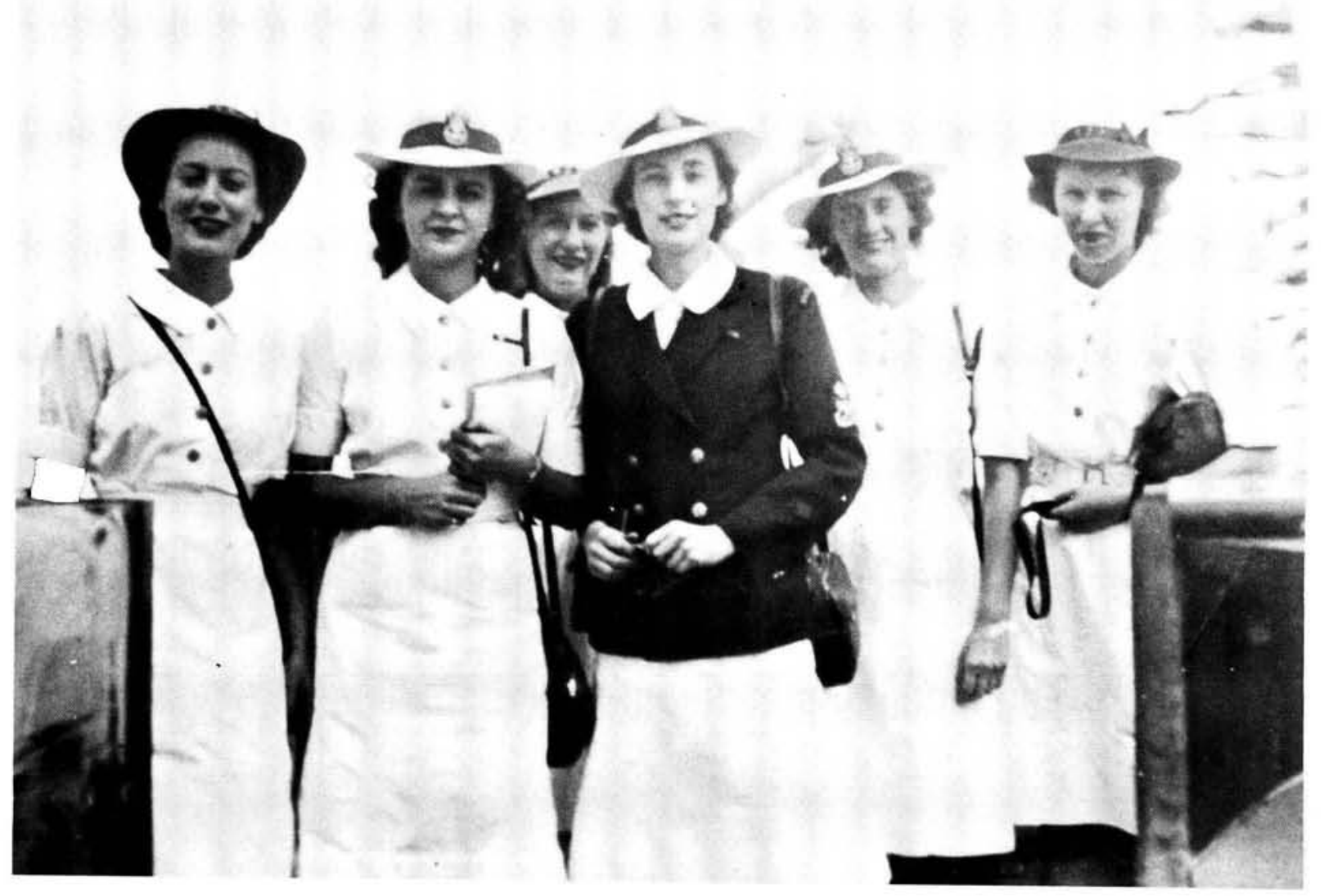

SWANS visit HMS VANGUARD in 1947. 
should be abolished on 1 December $1949 .{ }^{12}$ At the suggestion of Cdre F. J. Dean, OBE, Director, SANF 1946-51 the lion, the crest of our national coat of arms, was chosen as the naval emblem and a special supplement to Commando in December 1950 included the new rating's winter uniform and the lion emblem which was to replace the orange diamond above the gold rank lace on officers' sleeves and shoulder straps.

The new rating's winter uniform closely resembled the blue battledress worn by $\mathrm{RN}$ officers but lacked blouse pockets, brass buttons and epaulettes. The RN naval collar was retained but was somewhat smaller, had two white lines instead of three and was different in shape to that previously worn. - The blue cap has been described in The Sailor as Russian but probably more closely resembled that worn by the German Navy. ${ }^{13}$ The dicky and cap tally were retained. Ship cap tallies, 'S crown and fouled anchor A' cap tallies and one for the Naval Gymnasium bearing the latter word only were worn. Summer uniform was similar with a white uniform of the same design as the blue one. Cloth shoulder titles bearing the letters $S A$ replaced the unilingual SOUTH AFRICA ones. These were also worn by senior ratings whose uniforms were otherwise unchanged.

Although the Naval Officers' Association of Southern Africa initially gave their 'reluctant support' to the new uniform, the announcement early in March, 1952 that the letters 'HM' were to be abolished caused great disconsolation among former officers loyal to the Crown ${ }^{14}$. A report in Die Transvaler explained that the unilingual badges and cap tallies were being replaced with bilingual ones and that to manufacture a cap tally bearing the bilingual abbreviations and ship name would have been impracticable. ${ }^{15}$

The appearance of the new naval emblem took the fancy of an advertising department artist and the back cover advertisement in The Sailor of January 1952 showed the rank lace on the sleeve

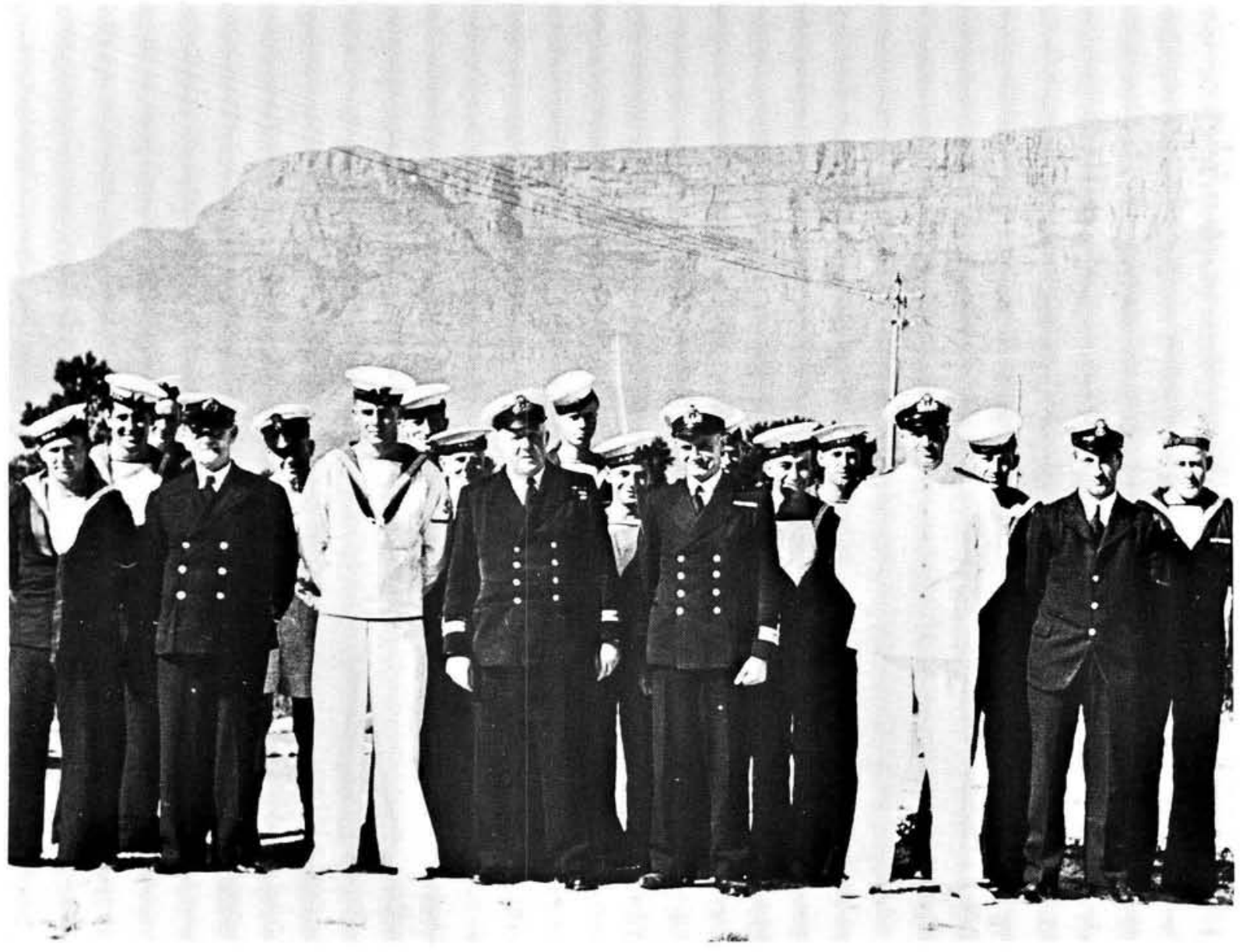

A variety of RN rigs: officers and ratings in HMSAS UNITIE during World War II. Notice the wartime austerity half rank lace worn by the Lieutenant-Commander, the single breasted jacket worn by the Petty Officer and the HMS cap tallies. 


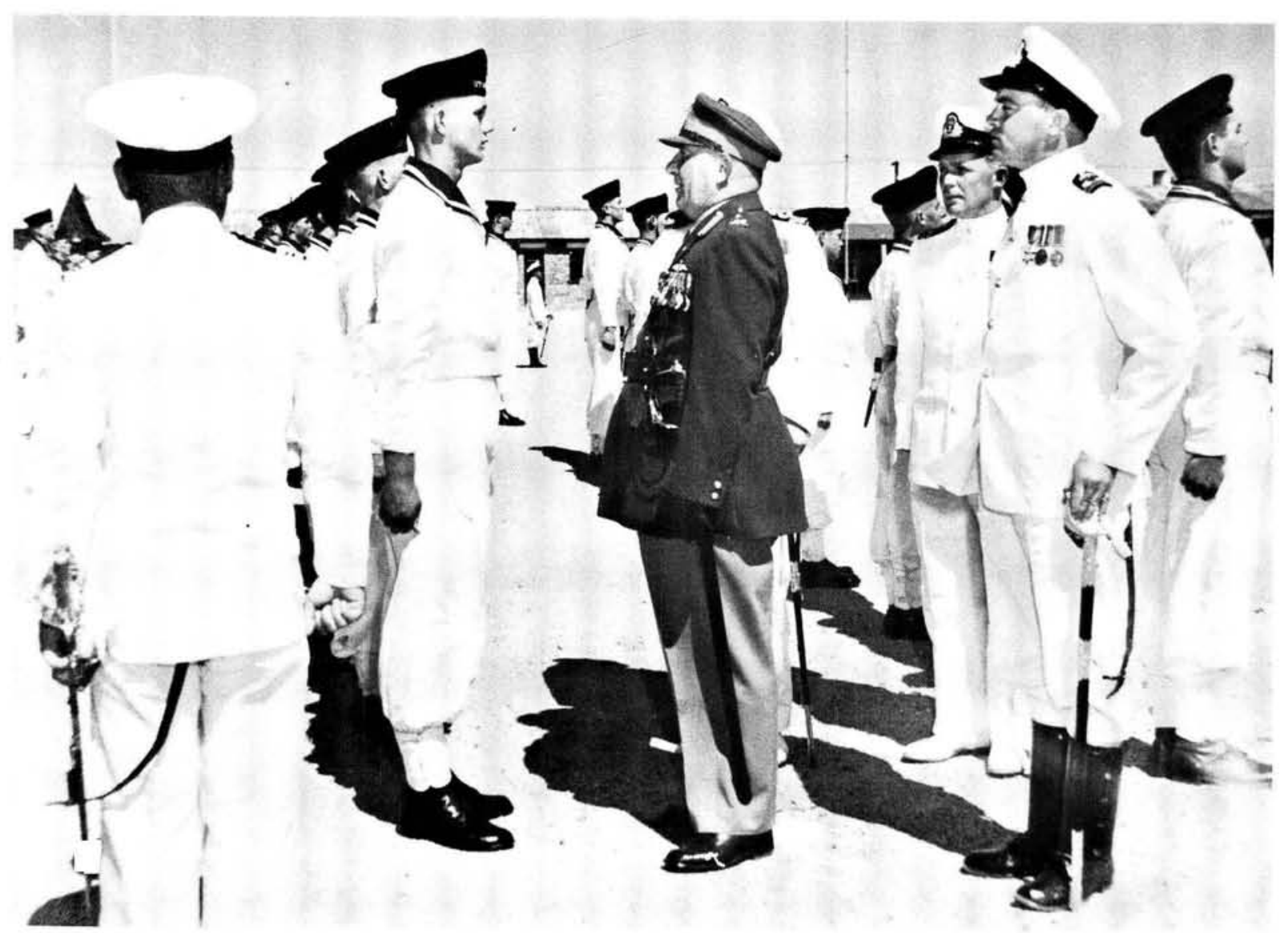

SA Naval Gymnasium ratings, wearing the SA Naval uniform worn from 1952-1954, being inspected by Maj Genl H. B. Klopper DSO, ADC. Lt now R. Adm P. A. H. Tomlinson, SM is the officer on the extreme right.

of a naval officer's winter uniform surmounted by a rampant lion bearing a bottle of beer in place of the four staves.

A caption in The Sailor records that many ratings objected to the new uniform because they said 'it made them the laughing stock of their girl friends'. ${ }^{16}$ By September 1954 the new uniform had been replaced by one very similar to the present one. Although a new cap badge for Petty Officers and below was introduced, a silver fouled anchor within a gold circle surmounted by the Naval lion, the RN cap badges worn by senior ratings and officers remained in use until circa 1960 when they were replaced with the present ones. In brief the 1954 SAN uniform for Leading Seamen and below was the RN uniform worn by Petty Officers and above. However the RN single breasted blue working dress jacket ('fore and aft rig') which had also been worn in the SANF was discontinued.

A special cap badge, a silver fouled anchor surrounded by a wreath of proteas and protea leaves and GYMNASIUM shoulder titles were adopted and worn by Gymnasium trainees. The former seems to have been replaced by the cap badge worn by Petty Officers and below in 1958 .

By 1961 SUID-AFRIKA (Right sleeve) and SOUTH AFRICA (left sleeve) shoulder titles had replaced the SA shoulder titles and were to be worn 'on the upper edge of each sleeve in line with the shoulder seam' by Permanent Force Warrant Officers and ratings. ${ }^{17}$ Similar shoulder titles with the letters AMB (Aktiewe Burgermag) and ACF (Active Citizen Force), changed to BM and CF after 1968, were worn by national servicemen and ACF ratings. SAKK/SACC shoulder titles were worn by SA Cape Corps naval personnel after they had been issued with naval uniform. The navy blue (later black) battle dress with which they were initially issued was the envy of their shipmates. In December 1968 a report on the simplification of SAN uniform badges described shoulder titles which were never worn by officers as 'redundant, unsightly and unnecessary because our uniforms are perculiar to the SAN'18 and they were later discontinued. The two cuff buttons worn by Petty Officers and below were discontinued after 1968. 
The only known photograph of these buttons may be seen opposite page 136 in the book No Pathway Here by Mr John Marsh.

From 1951-1955 the SA Corps of Marines had a brief but colourful existence. Although our marine uniform has been described as 'almost identically the same as that worn by the Royal Marines'19 there were a number of differences. An orange stripe replaced the red piping on the trousers and a black mohair cap band was worn in place of the red RM cap band. Although the Marines had their own cap and collar badges and buttons, photographs reveal that they wore those of the SA Artillery until these became available. It would seem that the issue of the popular marine uniform was limited to all ranks of the Permanent Force and officers of the Active Citizen Force. Other ranks in the ACF wore the usual SA Artillery uniforms. Unlike the Royal Marines, all ranks of the SA Corps of Marines wore a white shirt, black tie and navy blue service dress jacket whereas other ranks in the former wore tunics instead. Navy blue battledress was also worn by the SA Corps of Marines.
Three naval uniform changes were necessitated by the need to fill gaps in the $\mathrm{RN}$ rank structure which did not correspond to those of the Army and SAAF. In the RN and SA Navy there were a handful of commissioned warrant officers who wore the officer's cap badge and one thin stripe. The disbandment of the SA Corps of Marines in 1955 led to the creation of the non-commissioned ranks of Warrant Officer Class I and 2 in the Navy. Naval commissioned warrant officers were given CF commissions and the rank of commissioned Warrant Officer in the SA Navy was abolished. ${ }^{20}$ Rank badges similar to those worn by the other services are now worn by naval warrant officers who also wear a distinctive cap badge: the silver fouled anchor within a circle surrounded by a wreath of Proteas and surmounted by the naval lion.

For a short while in the early 1960's Acting Sub Lieutenants wearing the uniform of that rank were equivalent to 2 nd Lieutenants in the other services but this was later changed to the thin stripe previously worn by the commissioned Warrant Officers and the rank Ensign which is also

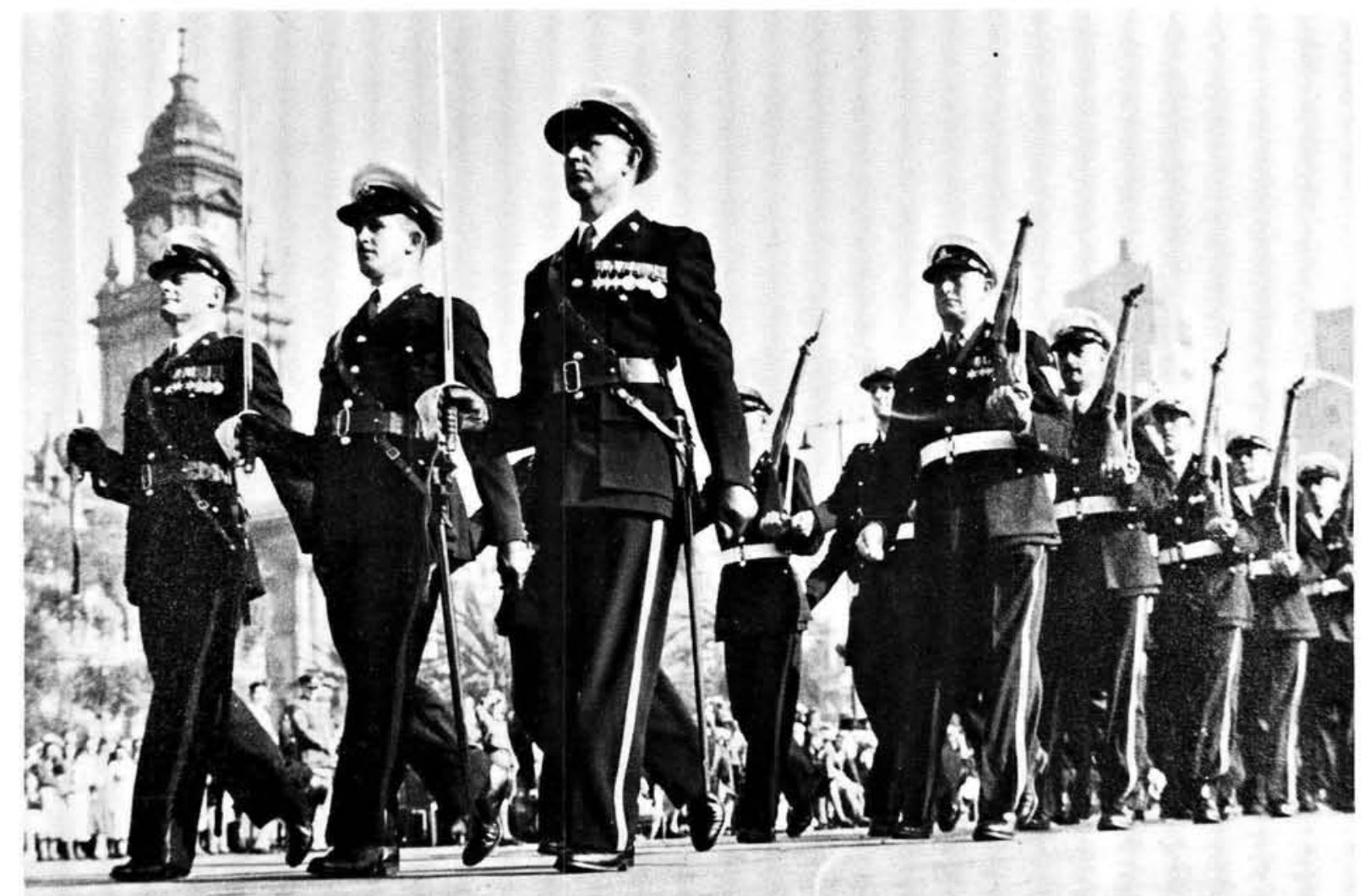

The SA Corps of Marines marching back to the Castle from the Grand Parade in Cape Town. Their SA Artillery insignia can be clearly seen. 
used by the United States Navy was adopted. In the Royal Navy the rank of commodore is only 'a temporary rank or appointment'. ${ }^{21}$ In the SA Navy it is now a substantive rank equivalent to the rank of brigadier in the other services. Only one South African, Commodore the Hon F. C. Sturrock, who was appointed Honorary Commodore (1st class) of the Seaward Defence Force (SA Naval Forces from 1942) has ever held this rank. The winter uniform of a Commodore 1st Class is identical to that of a Rear-Admiral but in summer uniform, the design on the shoulder straps, which at a distance appears similar to those of flag officers is decorated with a fouled anchor surmounted by a crown and two stars.

All the badges on our Flag Officers' shoulder straps were initially silver. The castles and lions are now silver wire badges. Further South African innovations include the letters $V$ worn by citizen Force officers and C worn by Cadet Officers' Training Corps (School Cadets) officers within the curl of their rank lace. Some important changes include the replacement of the RN blue winter uniform with a black one, the replacement of white drill uniforms with drip dry ones and caps with narrow peaks with caps with wider ones and built in white plastic tops. Plain brown leather gloves are no longer worn by SA Naval Officers.

The origin of the green turnbacks worn by Citizen Force midshipmen is not known. RNVR midshipmen wore maroon turnbacks and it would be reasonable to suppose that RNVR (SA) midshipmen did likewise.

Photographs of SA Naval personnel who served ashore during the State of Emergency in 1960 show officers and ratings wearing Action Working Dress, helmets, boots, anklets and webbing at Nyanga and Langa in the Cape Peninsula. Naval ratings at Wingfield are shown in the same rig with black berets instead of helmets. An officer at Wingfield is shown in working dress and a web belt with ammunition pouch and holster ${ }^{22}$.

With a few exceptions the RN branch distinguishing cloth which was also worn by our officers between or beneath their rank lace was abolished in 1955. In 1962 SA Naval medical officers wore scarlet, dental officers orange and chaplains mauve distinguishing cloth. Today welfare officers, pharmacists and nursing sisters all wear maroon and medical and dental officers wear scarlet distinguishing cloth.

Since 1 April 1968 all our naval chaplains save the
Assistant Chaplain General (Navy), formerly the Senior Staff Officer Chaplains (Navy), who wears the uniform of his rank (Captain, SAN), have worn the same uniform. Both the practice of naval chaplains having a naval rank and the present SA Naval Chaplain's uniform represent a complete break with RN custom. On their black jacket our naval chaplains wear a purple cuff band $7 / 16$ " in width with a gold band of 9/16" lace on either side thereof. The chaplains' insignia is worn in the centre of the purple band above which is the naval lion. Chaplains' shoulder straps are purple bonded by $1 / 4$ " gold lace and bear the chaplains' insignia surmounted by the naval lion. The naval officer's cap badge worn by chaplains bears a cross in place of the fouled anchor. All chaplains wear the cap worn by Commodores, Captains and Commanders.

On 5 September 1978 the Chaplain General requested that authority be granted for Naval Chaplains to wear the ordinary Naval officer's cap badge because it was felt that there were too few chaplains (10 PF, 2 CF and 6 NSM) to warrant manufacturing a special chaplain's badge and because the purple shoulder straps worn with summer uniform and the purple sleeve band worn with winter uniform clearly distinguish the naval chaplain from other officers. This request was approved by the Chief of the SA Defence Force on 15 September 1978.

The 1962 Dress regulations contained no rank badge for an Able Seaman and this gap has been filled by a five pointed star badge which was adopted after 1973.

In April 1971 Paratus published details of a new 'typically South African' Kalahari sand uniform for the SA Defence Force designed by Mr Hardy Amies from England and these included a new naval uniform. When the then State President, the Hon J. J. Fouche, DMS, said in a speech at a mess dinner for naval officers in SAS SIMONSBERG how sorry he would be to visit Simonstown in summer and not see the Navy's white uniform his words were greeted with loud cheers. The Hardy Aimes naval uniform was never worn and later abandoned. Only those who have witnessed the fights fought by sailors on liberty in defence of their uniform can begin to appreciate just how sensitive this issue is.

For many years different uniforms were worn by the Naval Police (formerly the Dockyard Police), Auxiliary Service personnel, Coloured and Indian naval personnel. SA Indian Corps Training 
Battalion (now SAS JALSENA) personnel wore the RN type 'white coat', white shirt and black tie in place of the white tunic in summer and a similar single breasted black jacket in winter. Admiral $\mathrm{H}$. $\mathrm{H}$. Biermann also wore the RN type 'white coat' as an undress summer uniform. Today all our male naval and naval auxiliary service personnel wear the same naval uniform.

Our present SWANS uniform includes a number of important innovations: a tricorn hat, single breasted long sleeved black jacket with three $7 / 8$ " gilt buttons and two 5/8" pocket buttons for ratings, black skirt, a white short sleeved open necked summer dress with five $7 / 8^{\prime \prime}$ gilt buttons, mess dress and white and black gloves. Although SWANS wear Action Working Dress trousers they also have a working rig dress with five $7 / 8$ " gilt buttons and were the first to wear the new black jersey which differs somewhat from the wellknown seaman's jersey. Another rig worn by Swans includes white shirt, black jersey and trousers.

As Naval and until 1955 also Marine Chief of Staff, Chief of the Navy, and finally Chief of the SA Defence Force it was natural that Admiral $\mathrm{H}$. $\mathrm{H}$. Biermann should have been one of the first, if not the first, to wear new SA Naval uniforms. A photograph of him which appeared in Commando, April 1954, page 43 shows him wearing what appears to be the then Army and SAAF gaberdine summer jacket and trousers, naval cap a darker coloured shirt, black tie, shoulder straps, ribbons and black shoes on his return from a conference in Dakar.

Photographs of Admiral Biermann on a visit to the Border in 1975 show him wearing an army type short sleeved bush jacket and trousers and naval cap and in other photographs a nutria army jacket over this uniform. Obviously special circumstances necessitated the most practical rig. A photograph taken on the same visit shows a SAN captain wearing nutria bush hat, shirt, trousers and naval shoulder straps and a Commodore in Action Working Dress. ${ }^{23}$ By 1974 bush hats (Army Pattern) were protective clothing for our divers. ${ }^{24}$ T-shirts athletic SA Army appear to be very popular with some of our submariners. ${ }^{25}$ The recent announcement that our sialors are to serve ashore on the Border will mean that the most suitable rig, the Army's nutria battledress which will soon replace Action Working Dress will be worn. It will be worn with black berets and black boots.

From the above it will be seen that the basic design of our 1954 pattern uniform has survived although a number of wise adaptations have been made. The decisions to permit the wearing of working dress by officers and the introduction of a new winter rig for all ranks which is essentially the old black undress uniform without the reefer jacket and with a new belt and new shirt are examples of these. The fact that all male naval personnel now wear the same uniform serves to remind the public that all South Africans are involved in the naval defence of the country and strengthens the Navy's already strong sense of identity.

The South African Navy is justly proud of its naval uniform which as has been shown is by no means simply a legacy from our origins in colonial naval volunteer units nurtured by the Royal Navy since 1885. Our naval uniform in common with those of countless other countries, does indeed reflect the immense influence of British naval uniform and doing so it provides our sailors with something all sailors need - a universally recognisable naval identity. Besides being seamanlike our naval uniform reflects equally clearly our own unique South African naval identity.

- Lt Cdr W. M. Bisset, is S. Military Musea, W P Command.

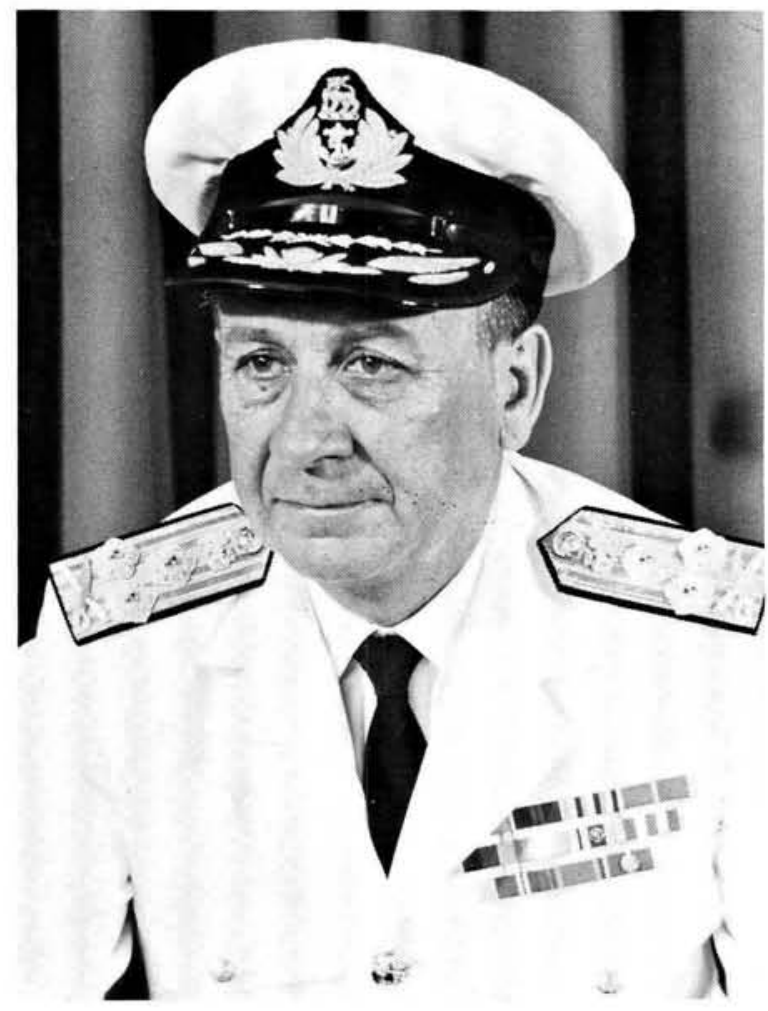

Admiral H.H. Biermann, SSA, SD, OBE wearing the RN type 'white coat' and the present pattern flag officer's shoulder straps with silver wire lions and castles. 


\section{Footnotes}

1. A. Mollo, Naval, Marine and Air Force Uniforms or Woria War 2. Blanford Press, 1975.

2. Lt A. J. Bateman, Simplification of Naval Uniform Badges (Report VSH 1/5/6/2) dd 2 December $1968 p 1$.

3. H. Knötel, Jnr and H. Sieg, Handbuch der Uniformkunde, 3rd Edn, Stand vom Jahre, 1937, Helmut Gerhard Schultz, Hamburg.

4. Paymr Lt Cdr E. C. Talbot-Booth, RNR. All the World's Fighting Fleets, London, circa 1938

5. A Mollo, op cit, $p 12$.

6. J Lennox Kerr and W. Granville, The R.N.V.R. A Record of Achievement, London 1957, p 23

7. Di A. P. Moore Anderson, Cape Town Naval Cadet Corps History and War Record, 1924 p 24.

8. Lt A.P. Burgers, A Short History of the South African Navy, Simonstown, 1967, p 13

9. Information supplied by Mr P. R. Humphries.

10. Information supplied by Car. W. J. van der Merwe.
11. Information supplied by Cdre J. C. Goosen, SM.

12. Brig M. de Villiers, 'Uniforms SA Permanent Force' in Commando, March 1954 p 44.

13. The Sailor, September 1954, p 11.

14. The Sailor, April 1952, p 2.

15. Quoted in The Sailor, April 1952

16. The Sailor, September 1954, o 11.

17. SA Naval Regulations and Instructions: Chap 15 : Uniform and Dress Regulations 1962 p 33.

18. Lt A. J. Bateman, op cit, $p 4$.

19. Brig M. de Villiers, op cit. $p 45$

20. Cdre J.C. Goosen, South Africa's Navy - The First Fifty Years, Cape Town, 1973 p 116

21. Paymr Lt Cdr E. C. Talbot-Booth, op cit, D 165.

22. Commando. May 1960, p 5, 6, 8 and 9 .

23. Paratus, May 1974, pages 3 and 5.

24. SA Naval Regulations, op cit, p 36.

25. Scope Special Defence Force Supplement Part 2, 11 November 1977 pages 7 and 23. 